\title{
A methodological approach to the study of archaeological cereal meals: a case study at Çatalhöyük East (Turkey)
}

\author{
Lara González Carretero $^{1} \cdot$ Michèle Wollstonecroft $^{1} \cdot$ Dorian $_{\text {Q. }}$ Fuller $^{1}$ (D)
}

Received: 15 July 2016 / Accepted: 16 January 2017 / Published online: 16 March 2017

(C) The Author(s) 2017. This article is published with open access at Springerlink.com

\begin{abstract}
This paper presents an integrated methodology for the analysis of archaeological remains of cereal meals, based on scanning electronic microscopic analyses of microstructures of charred food fragments from Neolithic Çatalhöyük (Turkey). The remains of cereal foods as 'bread-like' or 'porridge-like' small charred lumps of various amalgamated plant materials are frequently recovered from Neolithic and later archaeological sites in southwest Asia and Europe. Cereal food remains have recently attracted interest because the identification of their plant contents, the forms of food that they represent and the methods used in their creation can provide unique information about ancient culinary traditions and routine food processing, preparation and cooking techniques. Here, we focus on three methodological aspects: (1) the analysis of their composition; (2) the analysis of their microstructure to determine preparation and cooking processes; (3) the comparison with experimental reference materials. Preliminary results are presented on the botanical composition and cooking processes represented by the charred cereal preparations found at Neolithic Çatalhöyük (Turkey), for example cereals processed into bread, dough and/or porridge.
\end{abstract}

Keywords Palaeoethnobotany $\cdot$ Near East $\cdot$ Food remains $\cdot$ Parenchyma $\cdot$ Neolithic

Communicated by A. Fairbairn.

Dorian Q. Fuller

d.fuller@ucl.ac.uk

1 University College London, Institute of Archaeology, 31-34 Gordon Square, London WC1H OPY, UK

\section{Introduction}

Notwithstanding its significance for human health and fitness, food has received much attention from archaeologists, anthropologists and ethnographers because of its fundamental role in the diverse cultural, economic and political developments of human societies (Lévi-Strauss 1964; Goody 1982; Hastorf 1991, 1998; Dietler 1996; Sherratt 1999; Wright 2000; Dietler and Hyden 2001). Archaeobotany and zooarchaeology as disciplines for the study of how plant and animal resources were used by ancient communities have seen significant growth, including the development of methods for recognising how food preparation techniques may be represented by preserved remains, such as evidence for butchery marks, bone boiling or roasting (Speth 2012; Munro and Bar-Oz 2005; Koon et al. 2010; Russell and Martin 2012). Yet the forms in which prehistoric peoples actually consumed their plant food resources have only recently received scholarly attention (Stahl 1989; Hansson and Isaksson 1994; Samuel 1994, 1999, 2000; Hansson 2002; Valamoti 2002, 2011; Wollstonecroft 2007; Wollstonecroft et al. 2008; Valamoti et al. 2008; Heiss 2014; Kubiak-Martens et al. 2015).

The form and content of ancient meals is important because it can help us to better understand culinary traditions and associated routine activities such as processing and cooking, as well as providing information about their species selection and intensification practices (Stahl 1989; Wollstonecroft 2007) and the nutritional value of the food (Wandsnider 1997; Wollstonecroft et al. 2008, 2011). Archaeologists have typically inferred this type of information from indirect evidence such as associated artefacts and features, such as grinding stones, mortars and pestles, hearths, ovens and ceramics (Wright 1994, 2000; Moore 1995). Significantly however, the inferences of 
archaeobotanists and zooarchaeologists are based on the analysis of direct evidence, archaeological plant and animal remains. Of particular note are recent archaeobotanical studies of organic residues in food crusts from pottery that combine organic chemical analyses and observations by scanning electronic microscopy (SEM) (Raemaekers et al. 2013; Oudemans and Kubiak-Martens 2013; Kubiak-Martens et al. 2015).

Cereals were central to the economic transformations associated with the so-called 'Neolithic revolution' (Childe 1936). These were amongst the first plants to be domesticated worldwide (Fuller et al. 2014) and they are the staple food for a variety of ecological systems nowadays, with wheat in Europe and North America, maize in parts of Africa and South America, sorghum in India and parts of Africa and rice in East and Southeast Asia. It has been suggested that cereals, with their hard, dry and storable seeds were the key support to the rise of early states and the development of writing systems (Steensberg 1990). Nevertheless, the systematic study of the forms in which people consumed their cereal food, whether as whole grains, bread, porridge, bulgur, or otherwise, has been limited.

The most commonly recovered archaeological evidence of cereal products, however, is in the form of charred amorphous fragments collected with routine archaeobotanical flotation. These are isolated lumps of processed plant foods also called 'bread-like' or 'porridge-like' materials. This type of plant remain has often been disregarded by archaeobotanists due to the complex methodology and time consuming analyses needed for their successful identification. As a consequence, more easily recognisable materials, such as whole loaves of bread have frequently received the attention of archaeologists. In this sense, Währen $(1989,2002)$ was first among them to offer a typological classification of the different types of breads recovered from European archaeological sites from the Neolithic to medieval times, based on their morphology.

Hansson and Isaksson (1994) pioneered the tissue-based analysis of amorphous charred fragments of processed food remains from several archaeological sites in Sweden, Västergarden, Vrå, Harrsjöbacken and Folåsa. Their study was the first successful application of SEM to identify the biological composition of the charred remains, which they augmented with chemical analyses. Building on this, Hansson (2002) carried out detailed analyses of whole loaves of bread from other Swedish sites such as Birka, Helgö, Ljunga and Boberget. Subsequently, over the last two decades, numerous in-depth tissue-based analyses of prehistoric and ancient breads have been published. Deserving special mention are Samuel's (1994, 1999, 2000) investigations of desiccated Egyptian bread from tombs in the New Kingdom (ca. 1550-1070 вC) which resulted in significant insights into ancient bread and beer making. More recent studies (Lannoy et al. 2002; Heiss et al. 2015), which focused on identifying the cereal components of Iron Age and Roman breads, demonstrate the usefulness of applying anatomical analysis to identify cereal tissue types; the results provide unique new information about the various ingredients used in bread preparation, as well as cereal processing techniques such as grinding, and various ways of preparing doughs and potential cooking practices. KubiakMartens et al. (2015) also applied SEM analysis to charred food crusts from pottery and isolated charred organic lumps recovered from late Neolithic sites in the northern Netherlands. Among the food ingredients, a range of plant-based cooked foods that included not only cereals but also fruits, nuts and tuber components were identified.

Another methodology was developed by Valamoti to investigate types of cereal foods that are not flour-based, such as bulgur wheat (Valamoti 2002; Valamoti et al. 2008). Ethnoarchaeological and experimental studies were combined on both cereals and pulses to investigate the form and composition of remains of cereal foods including observations of the intracellular features and changes in starch granule morphology.

Despite the recent increase in such studies, the analysis of archaeological remains of food is still very methodologically fragmented. A coherent methodology is needed to obtain a dependable assessment of taxa composition and possibly the identification of food processing methods from morphological changes to plant tissue (Antolin et al. 2016). It is thus the aim of this paper to present an integrated methodology for the analysis of archaeological remains of cereal foods. The methodology described here uses SEM observation to analyse the microstructures of amorphous charred food fragments from Neolithic Çatalhöyük, Turkey, which are compared with SEM observations of experimentally produced reference materials. We focus on three methodological aspects: (1) the analysis of their plant taxa composition; (2) the analysis of their microstructure to determine preparation and cooking processes; (3) the comparison with experimental reference materials.

\section{Neolithic Çatalhöyük plant subsistence}

Çatalhöyük, a 9,000 year-old settlement mound (tell) site in central Anatolia, Turkey, provides an ideal site for the study of Neolithic cooking practices and style or method of cooking and selected sets of ingredients, as well as changes in those practices over time. This site had a long and continuous occupation (7100-6000 cal BC and beyond; Table 1), which spans the introduction of pottery and, in the later levels, the introduction of domesticated cattle and use of secondary animal products. A variety of domed ovens (firin) have been identified at Çatalhöyük dating from the late 8th 
Table 1 Chronological system of levels at Çatalhöyük East and analysed charred fragments of processed plant food

\begin{tabular}{lllll}
\hline Mellaart levels & Hodder levels & Phase & Chronology cal BC & Food samples \\
\hline 0, I, II & TP6 & Late Neolithic & $6400-6000$ & 32 \\
& South T-4040.J & & - \\
& South S-4040.J & & 2 \\
& South R-4040.I & & 2 \\
& South Q-4040.H & & 4 \\
V & South P-4040.H & Middle Neolithic & & 15 \\
VIA & South O-4040.G & Middle Neolithic & $6500-6400$ & 12 \\
VIB & South N-4040.G & & & 13 \\
VII & South M-4040.F & Early Neolithic & $6700-6500$ & 6 \\
VIII & South L-4040.F & & & 2 \\
IX & South K & Early Neolithic & $7100-6800$ & - \\
X & South J & & & - \\
XI & South I & & \\
XII & South H & & \\
Pre XII & South G1, G2, G3, G4 & Pre-Pottery Neolithic & & 4 \\
\hline
\end{tabular}

millennium, and preceding the use of pottery as cooking vessels (Last et al. 2005). Çatalhöyük has also been extensively sampled for archaeobotanical remains, and produced rich and well preserved plant assemblages. Nevertheless, although food processing and cooking techniques at Neolithic Çatalhöyük were previously explored by Atalay and Hastorf (2006), the present study is the first methodological approach to the archaeobotanical analysis of charred food remains and their preparation at Çatalhöyük.

Çatalhöyük is located in south central Turkey on the Konya plain $\left(37.6664^{\circ} \mathrm{N}, 32.8257^{\circ} \mathrm{E}\right)$. After its discovery in 1958, it was excavated by James Mellaart and his team from 1961 until 1965. Renewed excavations by The Çatalhöyïk Research Project began in 1993 under the supervision of Ian Hodder. The site is divided into the East Neolithic Mound and the Chalcolithic West Mound, which represents the continuation of the occupation. As part of this project, our study focuses on material from the extensive occupation of the East Mound, dating from 7100 to 5950 cal вС (Bayliss et al. 2015). As a result of the last 20 years of excavation and research, Çatalhöyük is presently the most completely studied and detailed record of Neolithic households in the Near East. It is considered to represent a house-based egalitarian society in which every house in this Neolithic village had a similar role and function in routine activities such as daily food processing and food preparation (Hodder 2005, 2006, 2007, 2011, 2012, 2013).

Plant subsistence strategies are well understood there. Bogaard et al. (2013) highlight the importance of cereals and pulses as well as a core set of nuts and fruits as staple foods at Neolithic Çatalhöyük. The plant assemblage indicates consistent long-term use of six cereals: the hulled wheats Triticum monococcum (einkorn), T. dicoccum (emmer) and 'new' type glume wheat, described by
Jones et al. (2000) and by Kohler-Schneider (2001, 2003), Hordeum vulgare var. nudum (two- and six-row naked barley) and $T$. aestivum (bread wheat). Three pulses were also used, Pisum sativum (pea), Lens culinaris (lentil) and Vicia ervilia (bitter vetch). Also used were oily-seeded Descurainia sophia (flixweed), three nuts, Prunus dulcis (almond), Quercus sp. (acorn), Pistacia vera (pistachio) and two fruits, Celtis sp. (hackberry) and Ficus carica (fig). This core set of staple foods confirms that these early crops were used in combination at the household level, reflecting cultivation of annual seed crops alongside gathering of wild resources. While some of these assemblages can be inferred to have come from the use of animal dung as fuel, others are more directly related to the waste from human activities such as crop processing waste (Bogaard et al. 2013; Filipović 2014). Fairbairn et al. (2005) also demonstrated that residues raked out of fireplaces are the most concentrated deposits of charred plant material produced through routine practices; these primary deposits were subsequently re-used and deposited as secondary contexts in middens and as tertiary contexts in building fills and construction material.

\section{Materials and methods}

Among the macrobotanical remains present at the site, amorphous charred fragments of cereal products were among the ones most frequently recovered during sorting of flotation samples (Bogaard et al. 2013), but were not previously subjected to any systematic examination (Fig. 1).

More than 200 charred food samples, which span the chronological sequence, were collected from sorted flotation samples during the 2013-2015 excavation seasons at 

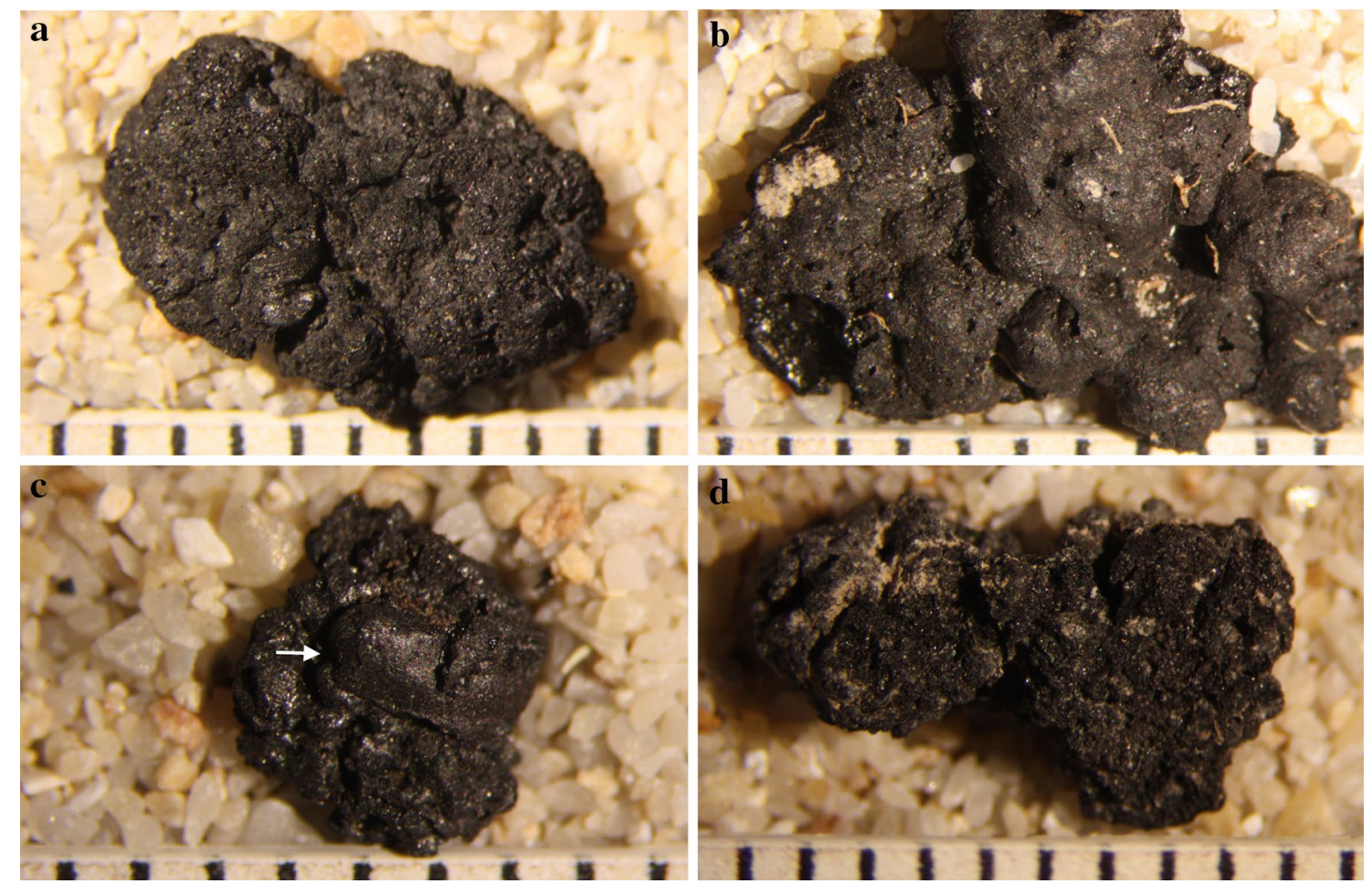

Fig. 1 Fragments of processed plant food from Çatalhöyük East: a Fl.10661; b Fl.11860; c Fl.10721; d Fl.9875

Çatalhöyük (Table 1; Filipović et al. 2014; Bogaard et al. 2015). The present paper summarises results of the study of 100 of the samples and illustrates a systematic methodology and terminology for investigating them.

\section{Field sampling}

Due the lack of previous methodology applied to the recovery of archaeological food remain samples, a new systematic procedure for their collection on site was developed for this study. For the initial recovery of macrobotanical remains, we followed sampling and processing methods developed during the 1990s excavations, including machine flotation and wet sieving (Hastorf 2005). Random subsamples of the 1-4 $\mathrm{mm}$ fraction of the flot were extracted with a riffle-box for sorting of an initial subsample of ca. $10 \mathrm{ml}$ to provide a first quantitative assessment of seed and chaff content, while the $>4 \mathrm{~mm}$ fraction was scanned for non-wood charred remains such as nuts, tubers and food fragments.

Flot samples which contained amorphous charred cereal remains during assessment were selected for further analysis. 200 flots containing these remains, from contexts that span the major phases of Çatalhöyük, were selected from the North, South and TP (Team Poznán) areas of the site during 2013, 2014 and 2015 excavation seasons. Initial scanning on site suggested that these samples were mainly representative of in situ food processing contexts such as ovens, hearths, fire spots and storage deposits as well as representing aspects of 'Neolithic recipes' before, during and after cooking. These samples were then sorted in their entirety of $>1 \mathrm{~mm}$ seed remains and smaller fractions were subsampled and scanned.

\section{Microscopy}

Several techniques have proved successful in previous research for the analyses of archaeological charred food remains or cereal products, from morphological to microanatomical tissue analysis and the application of chemical methods (Währen 1989, 2002; Hansson and Isaksson 1994; Kubiak-Martens et al. 2015). We chose to apply an integrated methodological approach which combined (1) microscopy: the study of microstructures and plant cell tissues under a low-powered binocular microscope; (2) more detailed characterisation with a scanning electron microscope, including the study of the food matrix through semiquantitative recording of voids and particles, and anatomical description of any included recognisable plant tissues; and (3) the experimental preparation of cereal foods to use as reference materials for comparison with the archaeological charred food remains.

Initial observation of the samples under a low-powered microscope was made using a Leica EZ4 binocular 
microscope at magnifications of $\times 8$ to $\times 40$; images were created using a Leica S6D microscope and a Leica EZ3 camera. From these, food fragments that showed visible plant inclusions such as plant tissues were selected for further study under SEM. For SEM observation, the samples were cleaned from soil sediments with a brush, sputter coated with ca. $20 \mu \mathrm{m}$ of gold, and examined using a Hitachi S-3400N scanning electron microscope. During the microscopic analyses, two main aspects were investigated: the identification of specific types of plant tissue in order to clarify the ingredients used for the preparation of these foods and also the exploration of their microstructures, which are a result of the processing and cooking techniques used for their preparation.

The first aspect of investigation is based on identification characters developed by Dickson (1987), Colledge (1988), Holden (1990) and Heiss et al. (2015) and botanical reference materials in the UCL Institute of Archaeology plant reference collection. Therefore the following plant tissues were considered, as previously tested by Heiss (2010, 2012) and Heiss et al. (2015): tissue layers present in the cereal grains (pericarp and seed coat), chaff (epidermis of paleas and lemmas), other parenchyma tissues (pulses and tubers), vascular tissues (tubers) and starch granules. These last, which are not easily preserved in charred material, can provide important information about processes used in food preparation (Samuel 1994; Valamoti 2002; Valamoti et al. 2008).

We are aware of no previous example of a cohesive and systematic methodology for the study of microstructures of amorphous charred food fragments, apart from the previously mentioned work by Hansson and Isaksson (1994) and brief mention of possible cooking processes in relation to their shape and consistency (Lannoy et al. 2002). Thus one of the main aims of this study was to create a specifically designed methodology for the study of microstructures of archaeological food remains. Two features in particular were chosen for further exploration: (1) cooking processes which could have created fewer or more pores (voids) in the food matrix and affected the quantity, shapes and types of voids; (2) various pre-cooking processes, such as different types of grinding techniques or various water contents and the cultural choices of ingredients which directly determined the types of particles present in the food matrix, and how they were preserved in the charred remains.

\section{Typological data sets for the analysis of microstructures of archaeological cereal products}

For the creation of reliable and accurate typological data sets for the analysis of the internal structures of archaeological charred cereal products, typological work on the description of different archaeological materials such as soil, sediments and pottery was explored. Based on comparison of pottery with cereal products such as bread, as the process in which 'a shapeless mass is first prepared, then given form, before being cooked in a kiln' (Lévi-Strauss 1988), we chose to build on the principles developed to study pottery fabrics in relation to porosity, hardness and inclusions, as developed for example by Washburn (1921), Grimshaw (1971), Rice (1998) and Mathew et al. (1991). In particular, voids are characterised to assess the nature of porosity, and included particles such as non-plastic inclusions in a pottery matrix can be characterised in terms of size, distribution and angularity of inclusions. In the case of food, these inclusions often contain anatomically recognisable fragments of plant cell tissues, but may also represent transformed amorphous starch.

Three attribute sets are used to describe the internal structure of the archaeological charred cereal food remains:

- Attribute set A focuses on the quantification and measurement of visible plant inclusions or particles in the food matrix, such as cereal tissues (Fig. 2).

- Attribute set $B$ focuses on the estimation, quantification and measurement of voids from air or gas bubbles in the food matrix (Fig. 3).

- Attribute set $C$ focuses on the typological classification of the previously quantified voids, in terms of void types and shapes (Fig. 4).

Following the different attribute categories described above, 100 food remains fragments were analysed by

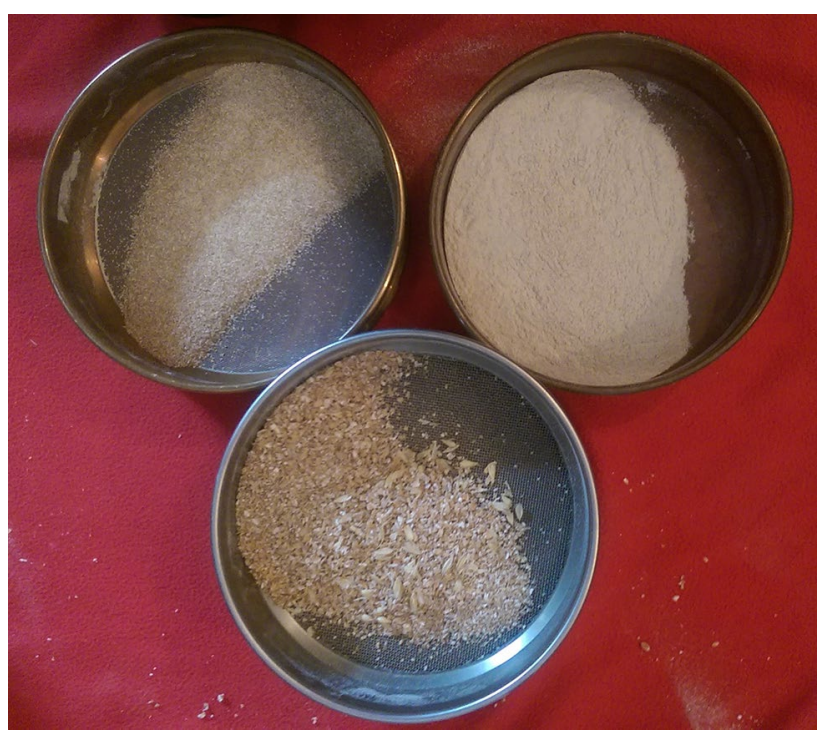

Fig. 2 Experimental flour types: fine $(<0.5 \mathrm{~mm})$, coarse grain or fine bulgur $(>0.5 \mathrm{~mm})$ and coarse bulgur $(>1 \mathrm{~mm})$ mixed with cracked grain and flakes 


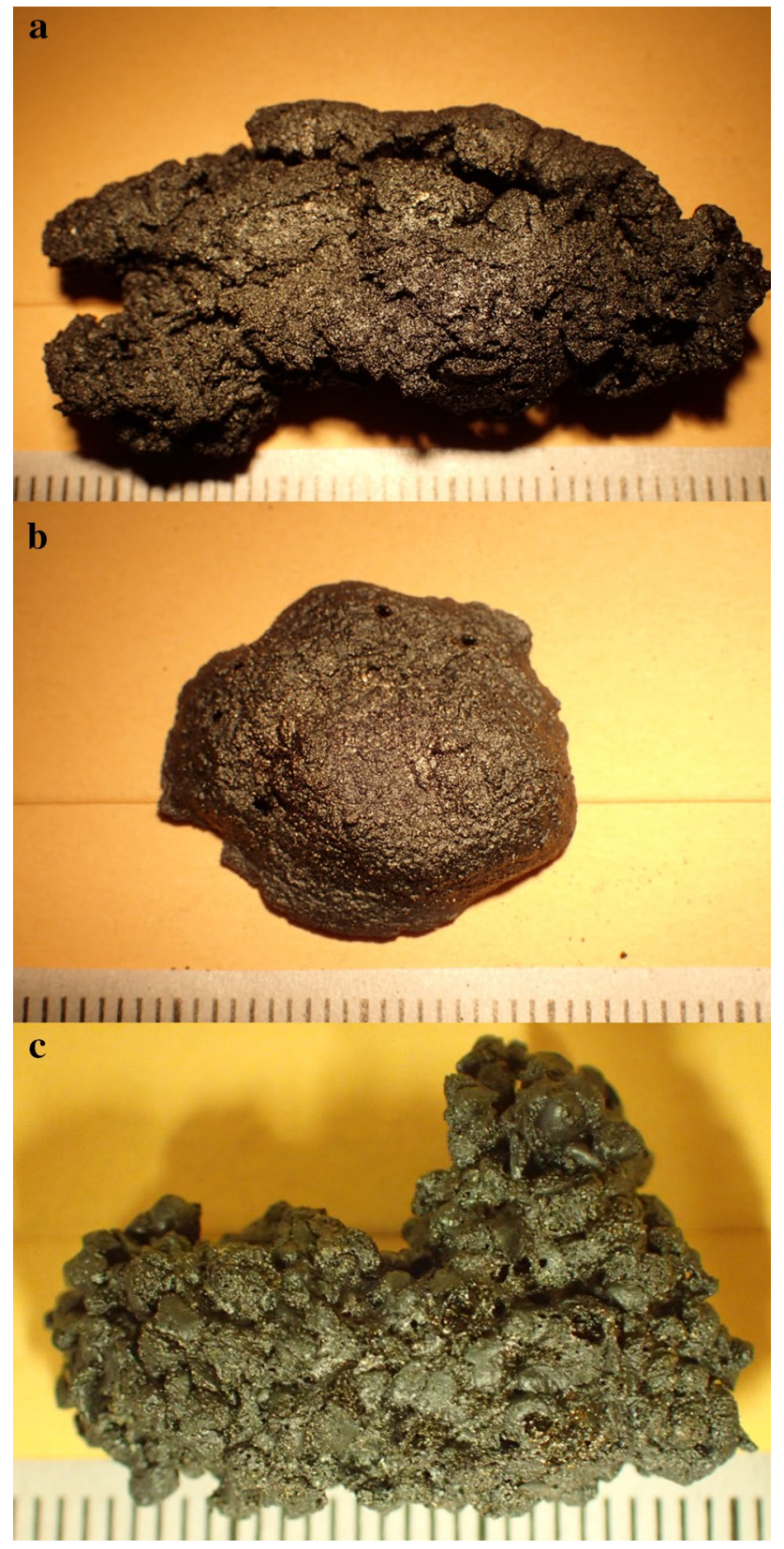

Fig. 3 Fragments of experimentally prepared cereal foods, charred at $300{ }^{\circ} \mathrm{C}$ for $3 \mathrm{~h}$ : a no water treated wheat flat bread; b no water treated wheat dough, $\mathbf{c}$ no water treated wheat porridge

SEM for specific observation of the matrix microstructures. During this, up to six images of the matrix of a food fragment were captured, at 16-20 mm working distance depending on fragment size and at $\times 50$ magnification, in order to cover the whole surface. Then the particles (Attribute A) and voids (Attributes B and C) were estimated, quantified, measured and categorised following a simple process.

First, visible particles or inclusions in the $\times 50$ magnification image were counted and the average was calculated when there was more than one image. Then each particle length was measured using the SEM Hitachi measurement tool and the average length of the particles was calculated.

Second, using the estimation chart, gas bubbles or voids visible on the $\times 50$ magnification images were quantified and measured. Voids were estimated, depending on their size and the percentage of matrix surface that they covered. Following the categories created on the charts, a mean size and an estimated percentage of voids in the food matrix were calculated. To minimise error, the percentage of voids was estimated again using Gwyddion, a free access modular program for SPM (scanning probe microscopy) data visualization and image analysis (by David Nečas and Petr Klapetek, Department of Nanometrology, Czech Metrology Institute). This allowed confirmation of the accuracy of estimates made by eye.

Third, the matrix was classified according to the shapes of the voids, based on the most frequent void shape encountered on the $\times 50$ magnification image.

\section{The preparation of experimental reference materials}

Experimental cooking and charring experiments are a major part of the methodology for this research study. Experimentally prepared and charred foods, which were created under controlled conditions, will serve as a reference collection for identifying the contents of the carbonised archaeological food fragments under study. Due to the previous identification of Çatalhöyük charred foods as "bread" (Bogaard et al. 2013) and also because of their frequent visible cereal inclusions in the matrix, cereal foods were chosen for this first set of experiments.

Different cereal grain materials were selected. Two types of cereals, wheat and barley, which are present in the archaeobotanical record at Çatalhöyük East (Bogaard et al. 2013) were chosen for this first set of experiments. Triticum aestivum was harvested in Dorset (UK) and cleaned prior to processing, while Hordeum vulgare was purchased already cleaned from fields in Germany through the fairtrade company Biolandhof Knauf. Both types of grain received three different treatments followed by different types of processing into three cereal products:

a. $200 \mathrm{ml}$ not water treated wheat or barley grain $\rightarrow$ ground into flour $\rightarrow$ dough, bread and porridge

b. $200 \mathrm{ml}$ soaked $(12 \mathrm{~h})$ wheat or barley grain $\rightarrow$ airdried $\rightarrow$ ground into flour $\rightarrow$ dough, bread and porridge

c. $200 \mathrm{ml}$ boiled (15 min) wheat or barley grain $\rightarrow$ airdried $\rightarrow$ ground into flour $\rightarrow$ dough, bread and porridge. 


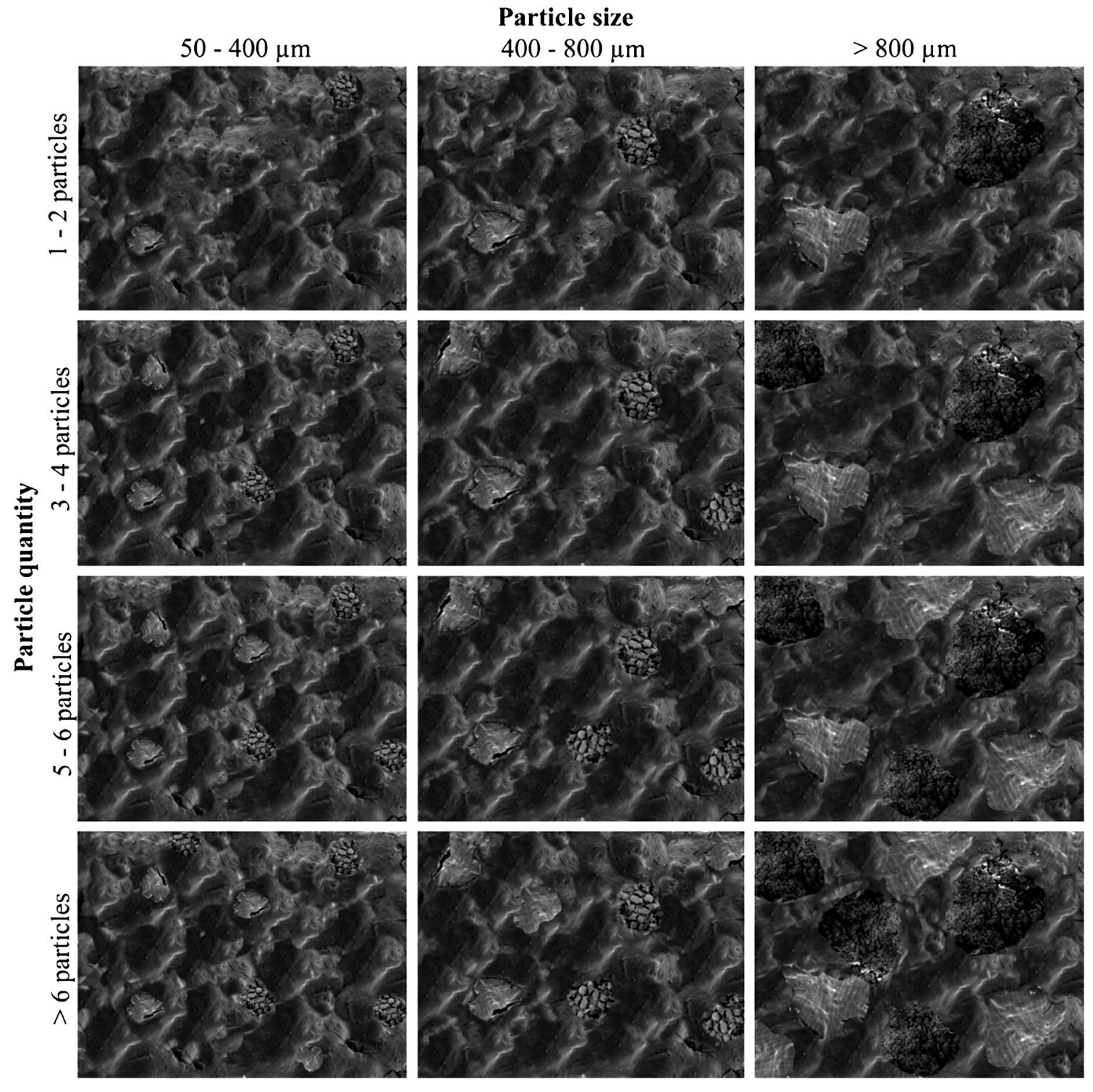

Fig. 4 Attribute set A: particles. Estimation chart based on size and quantity of visible plant particles in the matrix

\section{Grinding}

Grinding was done until a majority of fine flour was produced (45 min to $1.5 \mathrm{~h}$ ), using an andesite hand stone and quern measuring $40 \times 18 \times 11 \mathrm{~cm}$. To grind, a small handful of grain was placed on the middle of the quern and short strokes with the hand stone broke down the grain and easily ground it into flour. Soaked, boiled and dry wheat and barley grain were all ground to fine flour using this technique. After grinding, the flour was sieved using two different geological sieves, 1.0 and $0.5 \mathrm{~mm}$, the mesh sizes of which resemble ethnographical examples. Three different types of flour resulted from the sieving: fine $(<0.5 \mathrm{~mm})$, coarse grain or fine bulgur $(>0.5 \mathrm{~mm})$ and coarse bulgur $(>1 \mathrm{~mm})$ mixed with cracked grain and flakes (Fig. 5).

\section{Preparation}

These three flours were then prepared into dough, flat bread and porridge or gruel following traditional methods previously observed in modern Turkish villages (Hillman 1973, 1981, 1984; Yakar 2000). For the preparation of the dough, $15 \mathrm{ml}$ of water was added to $25 \mathrm{ml}$ of a mixture of fine flour $(<0.5 \mathrm{~mm})$ and coarse grain $(>0.5 \mathrm{~mm})$. The different dough types were then kneaded for approximately $1 \mathrm{~min}$. For the preparation of the flat breads, $80 \mathrm{ml}$ of fine flour was mixed with $30 \mathrm{ml}$ of water and kneaded 


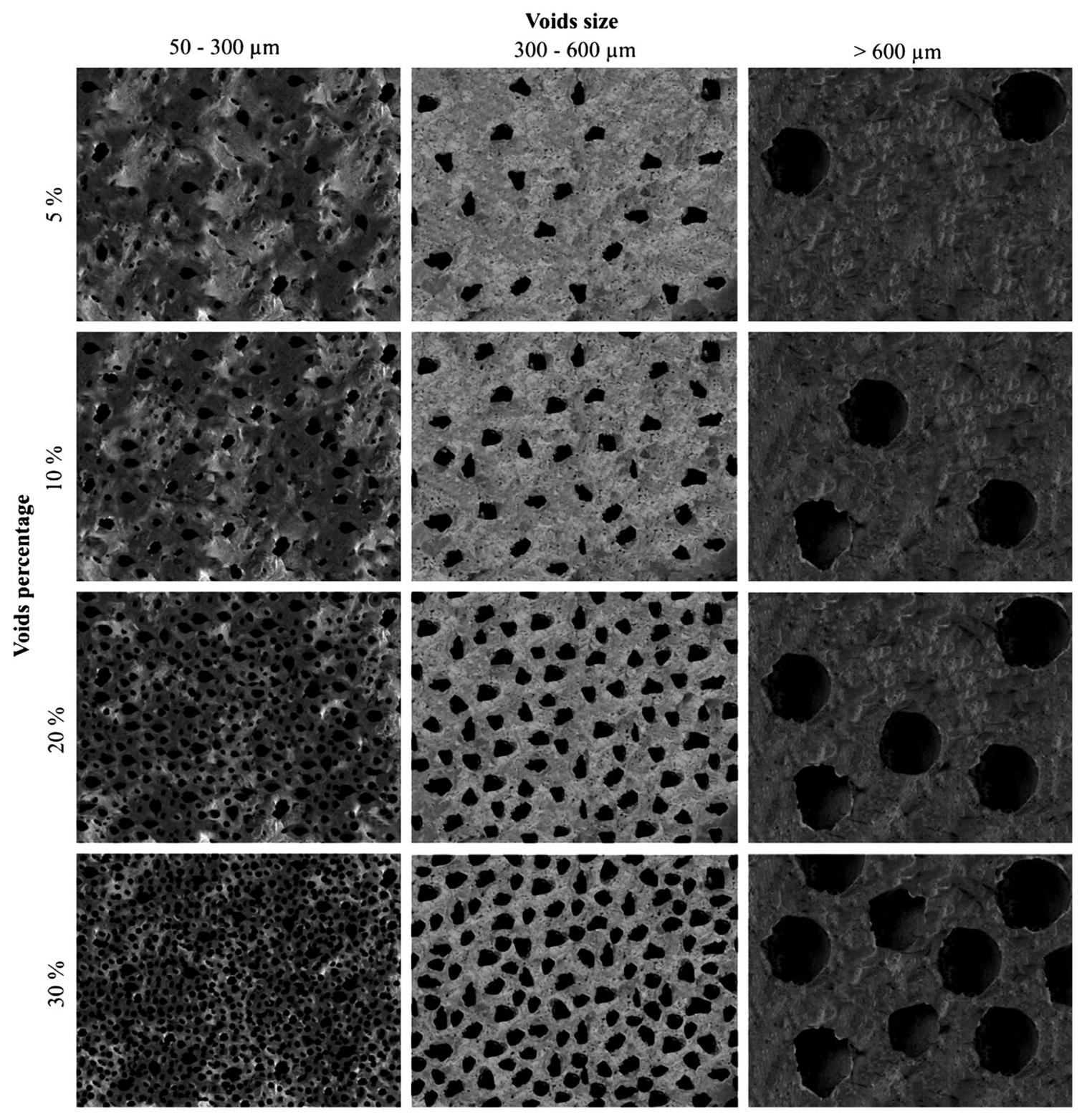

Fig. 5 Attribute set B: voids. Estimation chart based on size and percentage of voids (air bubbles) in the matrix

until the consistence of bread dough was reached. The dough was then put on a baking tray and baked at $180^{\circ} \mathrm{C}$ for $30 \mathrm{~min}$ using an electric oven. For the preparation of porridge, $100 \mathrm{ml}$ of the coarser meal produced $(>1.0 \mathrm{~mm})$ during grinding was added to $100 \mathrm{ml}$ of boiling water, then the mixture was boiled for 3 min until the consistence of a paste or gruel was reached and the water evaporated.

\section{Charring}

The charring experiments on the prepared cereal foods were then conducted using a muffle furnace at the Institute of Archaeology at University College London. Three similar sized pieces $(30 \times 15 \times 10 \mathrm{~cm})$ of each cereal preparation were charred at $300^{\circ} \mathrm{C}$ for 1,2 and $3 \mathrm{~h}$ in order to recreate a possible intentional burning and to understand the behaviour of the matrix, starches and tissues when charred for different times in the archaeological food remains (Fig. 6).

These experimentally created charred food specimens were then studied under low powered binocular microscope and SEM in order to compare the starch granules, plant tissue remains and matrix internal microstructure with the archaeological food remains from Neolithic Çatalhöyük. These charred specimens are the first set of materials which will form part of an extensive reference collection of charred food materials to help the future investigation into archaeological food remains. This will not only include 

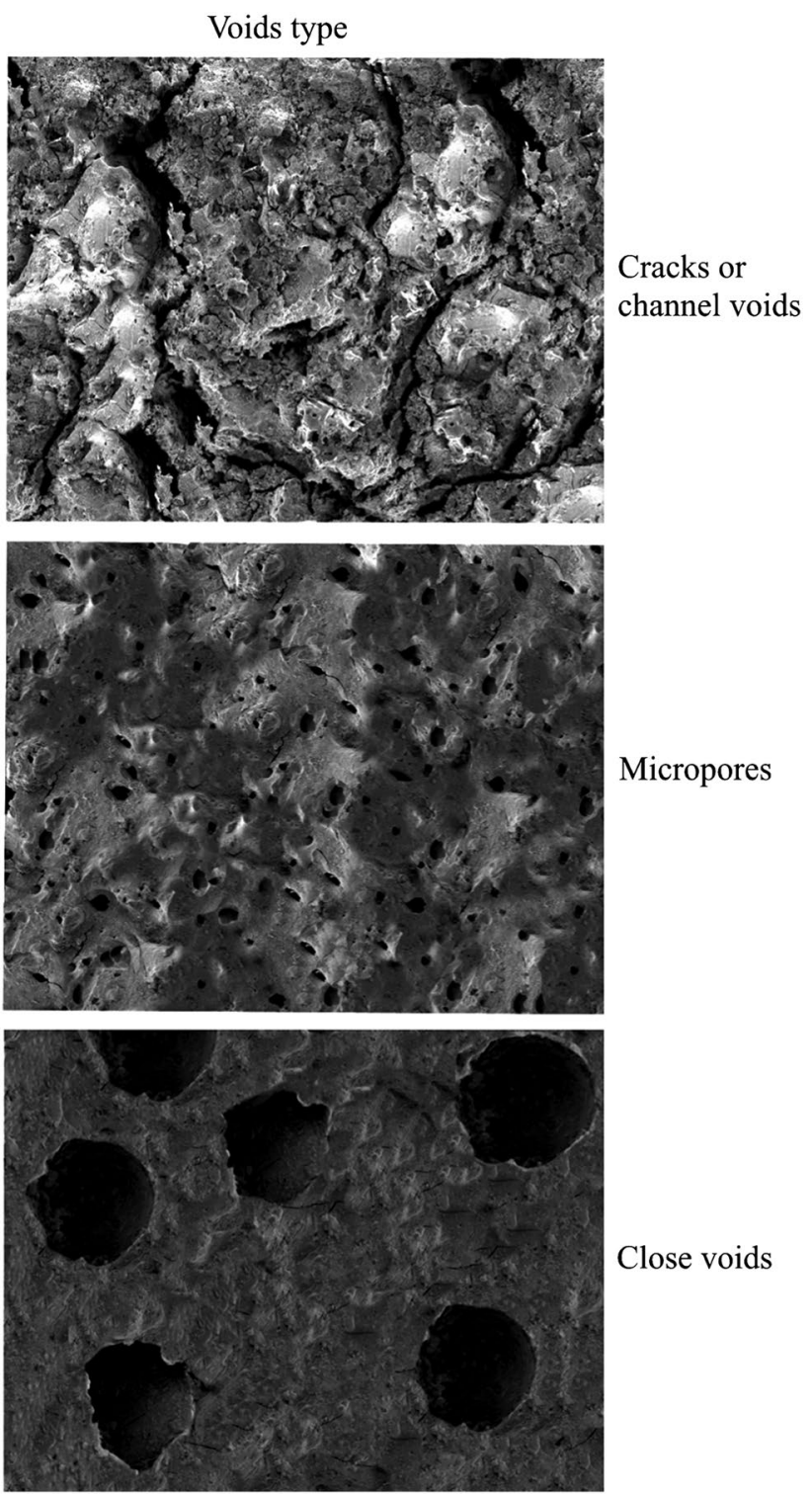

Fig. 6 Attribute set C: type of voids. Estimation chart based on shape of voids (air bubbles) in the matrix

a variety of cereal foods but also other food preparations such as legume flours and others.

\section{Results}

\section{Components}

Of the 200 archaeobotanical flotation samples selected from Neolithic Çatalhöyük, 172 contained charred food fragments that have provided information about their plant food components. The amount of archaeological food per sample varied between 0.1 and $20 \mathrm{ml}$ and the sizes of these fragments were from 0.1 to $2.4 \mathrm{~cm}$. These food fragments were all seen to have a starchy microstructure and irregular porous matrix, which together indicate well-processed and cooked plant components, with cereals as the main ingredient. Seen under the binocular microscope, plant remains, mainly cereal components and tissues, appeared as small shiny areas on the charred food materials. However, identification of specific tissue types and taxa was only possible by SEM.

For this study, 100 charred food fragments have been fully analysed under SEM and categorised according to the typological datasets explained above. Almost all samples chosen are from primary deposits, mainly burnt in situ contexts, and they cover the full Neolithic sequence at Çatalhöyük East, from the earliest level on site, Hodder Pre-pottery South G (Mellaart Level Pre XII), to the TP S Hodder Level (Mellaart Level 0) which is considered the latest Neolithic level found to date. From the 100 food fragments, 93 have provided information about their plant food components, with $91 \%$ of the remains comprised of cereals (wheat and barley).

There is a general consistency in the plant food components of the 100 food fragments. To assess the probability of these being remains of cereal foods as suggested by previous observation (Bogaard et al. 2013), we chose to separate visible plant tissues into different categories. These categories are based on a clear distinction between cereal and non-cereal components. The majority of identified tissues are internal tissues of the cereal grain. Among these, pericarp tissues such as bran layers (transversal and longitudinal cells) and endosperm cell structures such as aleurone layers and endosperm starch containing cells were observed (Fig. 7).

Only $8 \%$ of the components observed under SEM were non-cereal components, some of which were recognised as fragments of pulses, based on the identification of the distinctive Vicia ervilia and Lens culinaris testa patterning in samples Fl.3099, Fl.10770, Fl.10798, Fl.11137, Fl.11235 and Fl.11240 (Fig. 7f, g; Butler 1990). Other non-cereal components have been identified as "wild" food components such as Descurainia sophia which is present at Neolithic Çatalhöyük in large quantities in storage and cooking contexts, from sample Fl.3099 recognised by the distinctive shape and seed coat (Fig. 7e). Also, the material from finely ground sedge tubers was given the preliminary identification to the species Bolboschoenus glaucus in samples Fl.7928, Fl.8641 and Fl.10664, as suggested by the shape and organisation of parenchyma cells and vascular bundles (Wollstonecroft et al. 2008, 2011).

In some cases, an identification of cereal components to genus level (wheat and barley) has also been possible, due to their cell and tissue shapes, sizes and patterning. Among the recorded components, visible broken grains, bran fragments and patches of aleurone tissue were very abundant: 


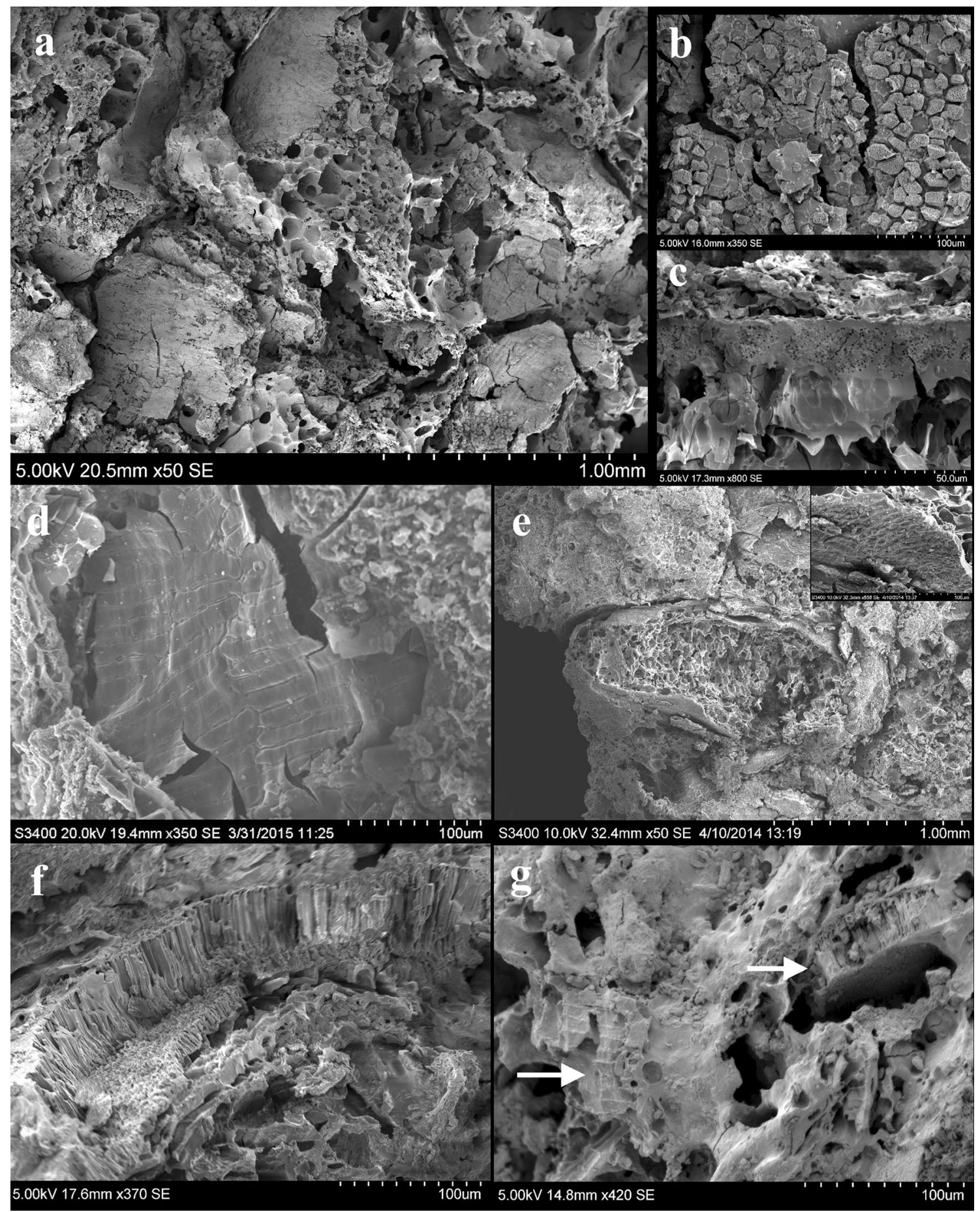

Fig. 7 SEM micrographs showing plant components in food fragments: a Fl.9822, Hordeum grain and bran fragments embedded in food matrix; b Fl.7860, remains of aleurone layer from food fragment; c Fl.10742, unicellular aleurone layer from food fragment; d Fl.6939, fragment of cf. Triticum bran transverse cells; e Fl. 3099,
Descurainia sophia seed embedded in food matrix and detail of seed coat; f Fl.11137, remains of visible pulse palisade cells layer; g Fl.11240, remains of pulse palisade cells layer and cereal bran, marked by arrows, mixed together in food matrix
- Fragments of cereal grains broken cereal grains were found in 22 of the 100 analysed food fragments. The identification of a broken grain of $H$. vulgare var. nudum was possible in Fl.9822 due to its distinctive shape, rippling surface and a fragmented double-layered aleurone (Fig. 7a). Also in Fl.10967 and Fl.11177 two fragments 
of $H$. vulgare grains were identified from the specific disposition of bran transverse cells measuring $\sim 30-70$ by 10-20 $\mu \mathrm{m}$ on the surface (Dickson 1987). Wheat grains have also been identified; one almost complete (cf. Triticum) in Fl.10661 and a fragmented specimen exhibiting the grain cross-section with single-layered aleurone and endosperm cells in Fl.3099.

- Bran fragments of bran, which included longitudinal and transverse cells, were by far the most commonly found particles among the food remains. They occurred in 85 of the 100 analysed samples, from 50 to $1,200 \mu \mathrm{m}$ in size. The distinction between cf. Triticum and Hordeum sp. transverse cells was made following criteria established by Dickson (1987), Holden (1990) and Colledge (1988). Good examples of these components were found in a $1.5 \mathrm{~mm}$ area of long and narrow cf. Triticum transverse bran cells $(70-280 \times 10-18 \mu \mathrm{m})$ from Fl.3666 (Fig. 7d) and shorter transversal cells $(30-70 \times 10-20 \mu \mathrm{m})$, distinctive of Hordeum species from Fl.10553.

- Aleurone tissue fragments of both single-layered aleurone tissue fragments as in wheats, oats, millets and rye and multi-layered ones (only in barley) were found in 61 of the 100 analysed food fragments. Fl.3099, Fl.6939, Fl.9924, Fl.10570 and Fl.10661 contained single-layered aleurone tissues that are distinctive for wheat (Fig. 7b, c); in Fl.9822 and Fl.9016, a barley double-layered aleurone is clearly visible.

In addition, a small quantity of cereal chaff was identified among the food fragments. Partial remains of glume epidermis could be seen in Fl.3666 and Fl.9016 with no further species identification; a complete barley rachis was visible in Fl.9822. Its identification was possible through the observation of the typical Hordeum glume epidermis "twin" arrangement of two short cells with a larger crescent shaped cell encircling a smaller circular one (Winton and Winton 1932).

\section{Morphology and microstructure}

Once we applied the typological datasets created for the present study of archaeological food remains, we were able to distinguish four different types of internal structures in the matrices of the materials recovered from Neolithic Çatalhöyük (Table 2):
- Matrix Type 1 Very few and small visible particles $(0-2 ; 50-300 \mu \mathrm{m})$ and large close voids (see typological attribute C) from 500 to $800 \mu \mathrm{m}$ which cover a high percentage of the microstructure surface $(>30 \%)$ (Fig. 8a, b).

- Matrix Type 2 A few small visible particles (1-3; 50-300 $\mu \mathrm{m})$ in which the air bubbles or voids are micropores (100-200 $\mu \mathrm{m})$ and cover more than $30 \%$ of the surface (Fig. 8c, d).

- Matrix Type 3 A few small visible particles (1-3; 50-300 $\mu \mathrm{m})$ and a low percentage of micropores (100-200 $\mu \mathrm{m})$, covering between $5-10 \%$ of the surface (Fig. 8e, f).

- Matrix Type 4 Lumpy matrix with a very large number of large visible particles $(>6 ; 500-1,300 \mu \mathrm{m})$ and a medium percentage of large cracks and channel voids (10-20\%) (Fig. 8g, h).

The first three types of matrices are characterised by a few (0-3) small visible particles $(50-300 \mu \mathrm{m})$ and have been observed in the food remains from the South and North areas at Çatalhöyük East from Levels South G to South S (7000-6400 cal BC). On the other hand, the fourth type of matrix which contains larger $(500-1,300 \mu \mathrm{m})$ and numerous $(>6)$ visible plant particles including grain fragments, large areas of cereal bran, etc., has so far only been found among the food fragments recovered from the latest levels at the site, in the TP areas (6400-6000 cal BC).

\section{Comparison with experimental materials}

The first set of experiments in the present study provides insights into the Neolithic food processing and cooking techniques at Çatalhöyük East.

Firstly, the pre-processing water treatments of the grain by soaking and boiling it affected the subsequent grinding process. Grain that was soaked or boiled became soft and showed higher resistance to grinding, making it more difficult to produce fine flour. Conversely, dry grain was easily ground into fine flour. Additionally, during the grinding experiments, $H$. vulgare proved to be more productive, resulting in $20 \%$ more fine flour than modern $T$. aestivum. Another observed advantage of $H$. vulgare over T. aestivum is that, when under the same environmental conditions,
Table 2 Matrix correlation between experimental and archaeological food samples

\begin{tabular}{lllll}
\hline Experimental & Archaeological & Attribute A & Attribute B & Attribute C \\
\hline Dough & Matrix 1 & $0-2 ; 50-300 \mu \mathrm{m}$ & $>30 \% ; 500-800 \mu \mathrm{m}$ & Close voids \\
Flat bread & Matrix 3 & $1-3 ; 50-300 \mu \mathrm{m}$ & $5-10 \% ; 100-200 \mu \mathrm{m}$ & Micropores \\
Porridge & Matrix 4 & $>6 ; 500-1,300 \mu \mathrm{m}$ & $10-20 \% ; 200-500 \mu \mathrm{m}$ & Cracks, channel voids \\
\hline
\end{tabular}


Fig. 8 SEM micrographs showing different food matrices identified from processed foods at Çatalhöyük East: a, b Matrix type 1; c, $\mathbf{d}$ Matrix type 2; $\mathbf{e}$, f Matrix type $3 ; \mathbf{g}$, h Matrix type 4

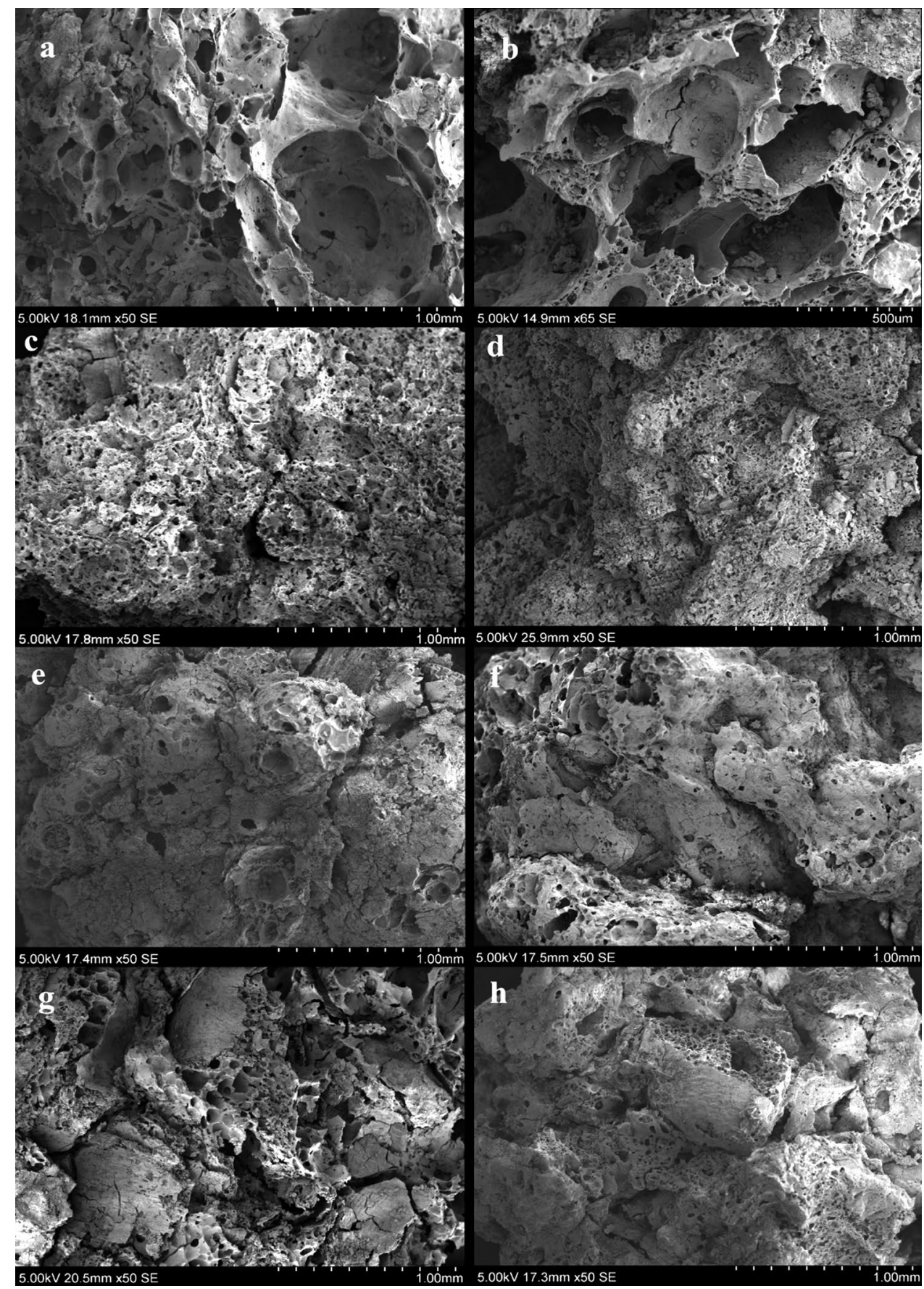

soaked and boiled Hordeum dried out in less than $2 \mathrm{~h}$, while soaked and boiled Triticum never dried completely.

Secondly, during the preparation of the three different types of cereal foods, dough, bread and porridge, the flour produced from dry grain was more suitable for bread making, but flour produced from wet grain appeared compacted and was more difficult to prepare into soft and elastic dough. Bread wheat proved to be more suitable for bread and dough making than $H$. vulgare since due to its high gluten content $T$. aestivum provides the necessary viscosity (thickness and texture) and elasticity to the mix. For the preparation of porridge however, boiled and soaked grain was shown to be better, taking less time to soften and producing a smoother paste. No clear differences in behaviour between wheat and barley were found during the preparation of porridge.

Lastly, during charring, although no real differences in behaviour were found between cereal taxa, the prepared cereal products responded differently to charring. While doughs completely carbonised during the first hour in 
the furnace, breads and porridges needed at least $2 \mathrm{~h}$ to char. These disparate behaviours are probably due to differences in water content of the foods. Also, the charring of doughs resulted in the formation of a crust on the outside and a hollow matrix inside; conversely, charring the breads resulted in almost no differentiation between crust and crumb.

The most significant results are thus from the comparison of the experimental charred cereal foods with the archaeological remains. Using the binocular microscope and subsequently the SEM, we observed striking similarities between the internal structures of the experimental foods and archaeological specimens. A close analysis following attribute $\mathrm{B}$ (void number and size) and attribute $\mathrm{C}$ (type of voids), revealed that experimental dough, bread and porridge had three different types of internal structure, which were almost identical to Matrix 1, Matrix 3 and Matrix 4 seen in the archaeological food fragments:
- Doughs had a hollow matrix, with large close voids (see Attribute C), 500-800 $\mu \mathrm{m}$, which covered more than $30 \%$ of their surface. This structure corresponded to Matrix 1 (Fig. 9a, b).

- Flat breads had fewer micropores (see Attribute C), 50-250 $\mu \mathrm{m}$ and which covered between $5-10 \%$ of their matrix. This structure corresponded to Matrix 3 (Fig. 9c, d).

- Porridges had a distinctive internal structure with channel voids and cracks (see Attribute C), which varied between 200 and $500 \mu \mathrm{m}$ in size and covered between 10 and $20 \%$ of the matrix. This corresponded to Matrix 4 (Fig. 9e, f).

Moreover, the same range of visible plant food particles, such as bran or grain fragments, was also found in the experimental specimens, with a marked correspondence in quantity and size among matrix types. For instance,
Fig. 9 SEM micrographs showing correlation between matrices from archaeological (left) and experimentally prepared food samples (right) : a, b correlation between Matrix type 1 and experimental doughs; $\mathbf{c}$, d correlation between Matrix type 3 and experimental flat breads; $\mathbf{e}, \mathbf{f}$ correlation between Matrix type 4 and experimental porridges

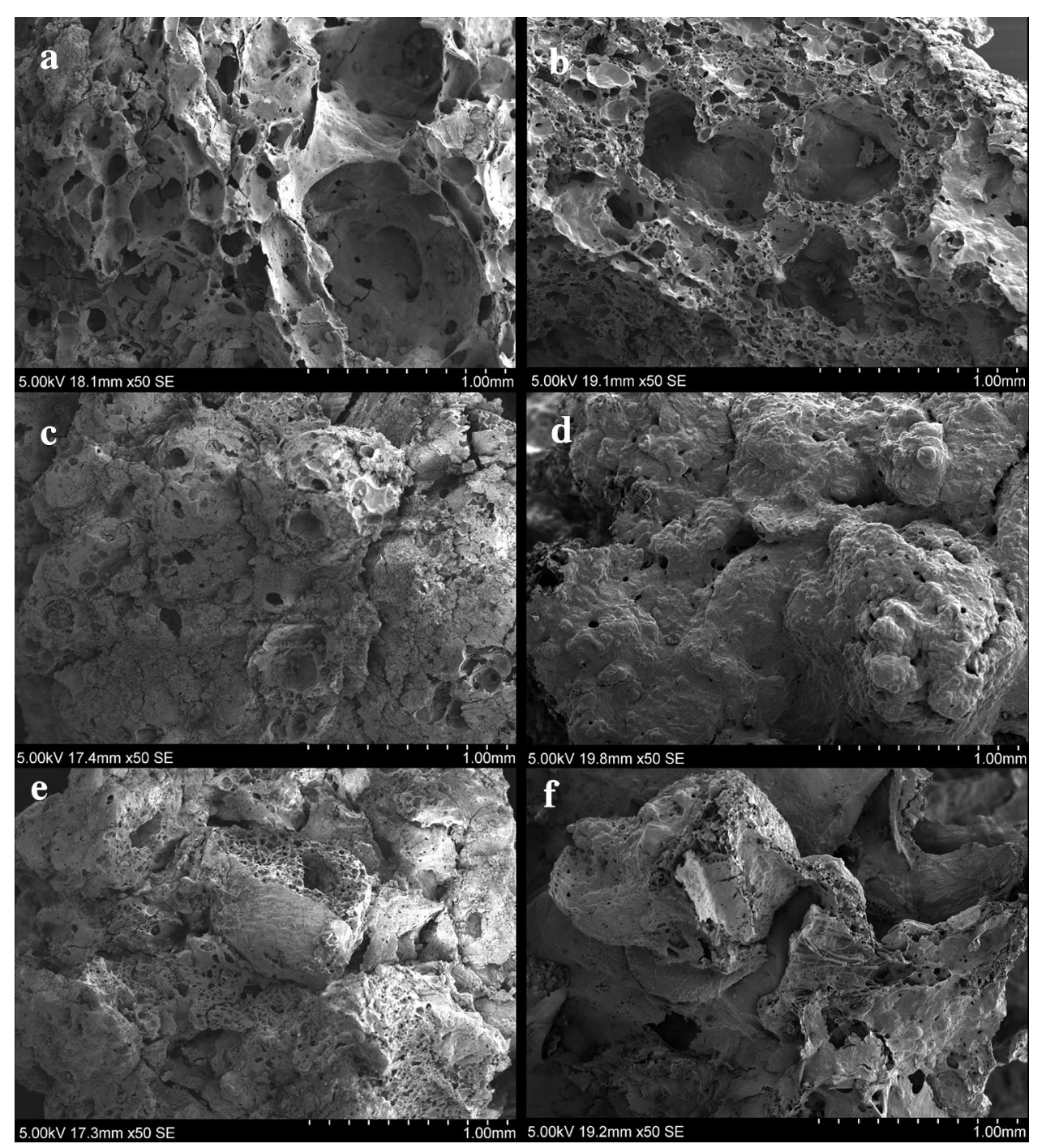


following Attribute A (particle quantity and size), experimental doughs and flat breads had a small number of visible particles (0-3) which varied in size 50-300 $\mu \mathrm{m}$; while porridges had a large number of visible food particles (5-10) with sizes between $500-1,500 \mu \mathrm{m}$.

\section{Discussion}

\section{Components}

Among the ingredients identified in the food remains, there is a consistency in the presence of domestic staple foods such as cereals and pulses in $93 \%$ of the analysed fragments. Among these, four pulses (Lens culinaris, Cicer arietinum, Pisum sativum and Vicia sativa), H. vulgare and Triticum spp. were the main ingredients of Çatalhöyük food remains. However, among the 100 analysed food fragments from Neolithic Çatalhöyük we also found two wild plant ingredients, the extensively used Descurainia sophia (Fairbairn et al. 2007; Bogaard et al. 2013) which has been identified in two of the 100 analysed food fragments, and a tuber of Bolboschoenus glaucus (as identified by Wollstonecroft et al. 2008; 2011) which so far has been found to be a component of three food fragments.

The further identification of Triticum spp. has not been possible yet, however in accordance with the macrobotanical remains from Çatalhöyük, the most likely wheat ingredients must have been either T. monococcum, T. dicoccum, 'new type' glume wheat or T. aestivum. Whether there were differences in the use of these cereals for food preparation between houses at the site is currently unknown, but we have clear archaeobotanical evidence of the abundant presence of these species throughout the Çatalhöyük sequence, at least for the North and South areas. In general, among the wheats, $T$. dicoccum/new type grains and glume bases outnumber those of T. monococcum and T. aestivum, which suggests that $T$. dicoccum/new type glume wheat was predominant throughout the sequence. Additionally, in the South and North areas, hulled barley is absent from early levels; it appears in Level South Q and North/4040 G and continues very sporadically in later levels (Bogaard et al. 2013). However, in the TP area, preliminary assessment indicates that hulled barley is more frequent (Bogaard et al. 2013; Bogaard and Charles, personal communication). In relation to the possible range of pulses, Pisum is the most common, Lens and $V$. ervilia occur in 10-20\% of samples, while Cicer arietinum (chickpea) occurs in a small minority of samples and in early levels at Çatalhöyük (Bogaard et al. 2013). The presence of Descurainia sophia throughout is constant, as large quantities of this oilseed were found in storage features in the South and North excavation areas (Fairbairn et al. 2007; Bogaard et al. 2013). Although the specific uses of this D. sophia at Çatalhöyük have not yet been explored, its intentional addition as an ingredient to the Çatalhöyük food would be among the earliest evidence of use of condiments in the Neolithic.

Although specific proportions of the cereals and pulses in the food fragments cannot be quantified due to the small surfaces observed in the analyses, there is a clear dominance of cereals and wheats in particular among them. Also, wheat particles outnumber barley components in samples from the North and South areas, while barley particles are more frequent among samples from the TP area. In relation to this, preliminary archaeobotanical results from burnt storage rooms in the TP area suggests a greater presence of barley (mostly naked) and 'new type' wheat than in the South and North areas. These patterns could be interpreted as possible changes in 'culinary choice', with an increase in the use of barley for food preparation towards the end of the Neolithic sequence at Çatalhöyük. However, the analysed contexts from TP are still very limited and further investigation is needed to assess the possible presence of other cereal types.

\section{Food preparation processes}

Based on the typological datasets created for this study and observations of the archaeological materials and their comparison with the experimental specimens, some preliminary conclusions can be drawn about the possible food preparation methods at Çatalhöyük East. We were able to identify four types of food matrices among the food fragments recovered from the North, South and TP areas, of which three were observed to be analogous to the internal structures of experimentally prepared dough, bread and porridge. While we see a varying presence of dough and bread-like fragments corresponding with Matrix 1 and Matrix 3 from the earliest Neolithic level South G to South S/4040J, porridge-like fragments like Matrix 4 have only been identified among the samples recovered from the latest Neolithic levels of the site from level South Q-North H onwards. While there are similar frequencies of dough-type and bread-type fragments throughout the South and North sequences, most of the TP food fragments (29 of 31) had a porridge-like microstructure, with large visible fragments of plant particles such as grain fragments, big bran areas, etc., cracks and channel voids.

The measured fragment sizes of pulse and cereal tissues indicate that the main component used for the preparation of the foods present in Matrices 1, 2 and 3 must have been fine cereal and pulse flour which had been sieved after grinding, or it had at least been subjected to repeated grinding. No tissue parts were visible to the naked eye; only five of the measured components exceeded a maximum length of $500 \mu \mathrm{m}$, while the major part measured between 100 
and $300 \mu \mathrm{m}$. According to Dickson (1990), without sieving, large bran fragments of $500 \mu \mathrm{m}$ length and above should have been visible in the respective cereal product. On the other hand, the measured broken grains, bran and chaff particles in Matrix 4 foods indicate that coarse grain must have been the main ingredient. This pattern might be due to shorter grinding periods or else due to an intentional choice of coarse grain over fine flour for the preparation of these foods. The possibility that these materials were not sieved has been considered, however due to the absence of small particles (100-400 $\mu \mathrm{m})$ they do not show a deliberate mixture of fine flour and coarse grain. Altogether, the fact that all visible particles range between $500-1,500 \mu \mathrm{m}$, in addition to the arrangement and type of voids and a lack of crumb structure, indicates a different cooking technique more related to a porridge or gruel preparation rather than bread baking (Dickson 1990; Lannoy et al. 2002).

\section{Conclusions}

Cereal agriculture was one of the key developments of the Neolithic in the Near East, which is considered to have supported growing populations by means of the storability of cereals and their suitability for high calorie foods. Among the characteristic cereal-based foods are different types of porridge-like and bread-like products, the latter based on flour preparation and baking. Bread has been suggested to be a characteristic of the cultural traditions of the Near Eastern Neolithic, in contrast to cereal-based Neolithic food systems in some other world regions (Haaland 2007; Fuller and Rowlands 2011). The Near East is one of a handful of world regions in which crop domestication took place in communities without pottery cooking vessels, in contrast to the early development of ceramics amongst foraging societies, for example in the African Sahara or in eastern Asia (Kuzmin 2013; Jordan et al. 2016). While flour production through grinding has long been inferred as central in Near Eastern cultural traditions, based on the preponderance of quern stones from before and during the Neolithic (Wright 1994, 2014; Fuller and Rowlands 2011), what has been less certain is when the preparation of bread began, and the relative importance of breads versus porridge or other preparations.

Bread is certainly central to the long-term cultural traditions in the Near East, in contrast to regions like Nubia (Haaland 2007) or eastern Asia where cereals were boiled earlier on and for cultural reasons (Fuller and Rowlands 2011). It was hypothesised that bread preparation may well have preceded cereal domestication, and may even be a factor in the preference for cereals with gluten protein, mainly Triticum and Hordeum, amongst early cultivars (Lyons and D'Andrea 2003; Rowlands and Fuller 2009; Fuller and
Rowlands 2011). The social importance of bread as a cultural foodstuff may have contributed to the importance of cereal consumption and may have been one of the factors that promoted cultivation and domestication (Maeda et al. 2016). Clay ovens certainly developed during the course of the Pre-Pottery Neolithic of the Near East, as for example at Tell Sabi Abayad II in Syria (Akkermans and Schwartz 2003; Akkermans et al. 2006), perhaps having developed from earlier pit ovens (Cauvin 2000; Fuller and Rowlands 2011). Nevertheless, finding out when bread became a periodic or routine food requires hard evidence.

The methods presented in the current paper provide a means to establishing both the presence and frequency of bread-like and porridge-like products as a food stuff. Ideally these methods should be combined with other approaches, such as organic analyses of food crusts from pottery, where this is possible. Large scale archaeobotanical flotation programmes can be expected to produce amorphous charred fragments from the remains of prepared foods, even from the period before pottery. Some of these charred "food lumps" can be categorised by microscopic analyses as probably deriving from bread-like preparations, porridge-like preparations, or others. While there are some categories of food remains that can be classified only descriptively, but for which we do not yet have an analogue food preparation with which to identify them (Matrix type 2), many others can be categorised as probably deriving from unbaked dough (Matrix type 1), bread (Matrix type 3) or porridge (Matrix type 4). As illustrated by our case study material from Neolithic Çatalhöyük, some food remains can be inferred to derive from bread and dough throughout the occupation, but these predominate throughout the earlier phases of the site occupation (ca. 7100-6400 BC). This fits with the idea that bread was already established and important during the Pre-Pottery Neolithic prior to and during the era when the site was founded. Of interest is that porridge type remains become prominent in the later phases at the site (ca. 6400-6000 BC), which correlates with periods in which pottery use increased (Last et al. 2005, p 102; Yalman et al. 2013) and in which domesticated cattle became important (Russell and Martin 2013), and with a probable increase in the use of dairy products (Copley et al. 2005; Evershed et al. 2008; Pitter et al. 2013). These data suggest that diversification of cereal-derived foodstuffs beyond bread to include more porridges took place together with diversification in ceramics in the early stages of the pottery Neolithic.

Acknowledgements We thank the support of the Çatalhöyük Research Project team and its director Ian Hodder. This builds on archaeobotanical research at Çatalhöyük overseen by Amy Bogaard and Michael Charles (University of Oxford). This research is part of a doctoral research project supported by an AHRC studentship awarded to Lara Gonzalez Carretero. Site based archaeobotanical research 
and laboratory work by Dorian Q. Fuller, Michèle Wollstonecroft and Lara Gonzalez Carretero was also supported by the Comparative Pathways to Agriculture project, a European Research Council grant (ERC Award No. 323842). We would also like to thank the organisers and the Swiss National Foundation for the opportunity to participate in the International Exploratory Workshop "Groats, bulgur, flour and semolina: archaeobotanical identification of cereal meals" (Basel, 2nd and 3rd of July, 2015).

Open Access This article is distributed under the terms of the Creative Commons Attribution 4.0 International License (http:// creativecommons.org/licenses/by/4.0/), which permits unrestricted use, distribution, and reproduction in any medium, provided you give appropriate credit to the original author(s) and the source, provide a link to the Creative Commons license, and indicate if changes were made.

\section{References}

Akkermans P, Schwartz G (2003) The Archaeology of Syria: From complex hunter-gatherers to early urban societies (c.16,000-300 BC). Cambridge University Press, Cambridge

Akkermans P, Cappers R, Cavallo C, Nieuwenhuyse O, Nilhamn B, Otte N (2006) Investigating the early pottery Neolithic of northern Syria: new evidence from Tell Sabi Abyad. Am J Archaeol 110:123-156

Antolin F, Alonso N, Berihuete M, Brombacher C, Chrondrou D, Ertug F, Garcia-Granero JJ, Gonzalez Carretero L, Hamon C, Heiss AG, Jacomet S, Naranjo Y, Perego R, Procopiou H, Steiner B, Valamoti S, Wojtczak D, Wollstonecroft M (2016) Grütze, Bulgur, Mehl und Griess. Jb Archäol Schweiz 99:143-151

Atalay S, Hastorf C (2006) Food, meals, and daily activities: food habitus at Neolithic Çatalhöyük. Am Antiq 71:283-319

Bayliss A, Brock F, Farid S, Hodder I, Southon J, Taylor RE (2015) Getting to the bottom of it all: a Bayesian approach to dating the start of Çatalhöyük. J World Prehist 28:1-26

Bogaard A, Charles M, Livarda A, Ergun M, Filipović D, Jones G (2013) Archaeobotany of the mid-later occupation levels at Neolithic Çatalhöyük. In: Hodder I (ed) Humans and landscapes of Çatalhöyük: reports from the 2000-2008 seasons. Monographs of the Cotsen Institute of Archaeology, Los Angeles, pp 93-129

Bogaard A, Filipović D, Charles M, Fuller DQ (2015) Macro and micro botanical remains. In: Hodder I (ed) Çatalhöyük 2015 Archive Report. BIAA, Ankara and London, pp 118-125

Butler A (1990) Legumes in Antiquity. A micromorphological investigation of seeds of the Vicieae. Doctoral Dissertation, University College London

Cauvin J (2000) The birth of the gods and the origins of agriculture. Cambridge University Press, Cambridge

Childe G (1936) Man makes himself. Watts \& Co, London

Colledge S (1988) Scanning electron tudies of the ell patterns of the pericarp layers of some wild wheats and ryes. Methods and problems. In: Olsen SL (ed) Scanning electron microscopy in archaeology. BAR Internat Ser 452, Oxford, pp 225-236

Copley M, Clark K, Evershed R (2005) Organic residue analysis of pottery vessels and clay balls. In: Hodder I (ed) Changing materialities at Çatalhöyük: reports from the seasons 1995-1999. McDonald Institute for Archaeological Research and British Institute for Archaeology at Ankara, Cambridge and London, pp 169-175

Dickson CA (1987) The identification of cereals from ancient bran fragments. Circaea 4:95-102
Dickson CA (1990) Experimental processing and cooking of emmer and spelt wheats and the Roman army diet. In: Robinson D (ed) Experimentation and reconstruction in environmental archaeology. Oxbow, Oxford, pp 33-39

Dietler M (1996) Feasts and commensal politics in the political economy: food, power and status in prehistoric Europe. In: Wiesnner PSW (ed) Food and the status quest. Berghahn Books, Oxford

Dietler M, Hyden B (2001) Feasts: archaeological and etnographic perspectives on food, politics and power. Smithsonian Institution Press, London and Washington

Evershed R, Payne S, Sherratt AG et al (2008) Earliest date for milk use in the Near East and southeastern Europe linked to cattle herding. Nature 455:528-531

Fairbairn A, Asouti E, Near J, Martinoli D (2005) Macrobotanical investigation of the north, south and KOPAL area excavations at Çatalhöyük East. In: Hodder I (ed) Inhabiting Çatalhöyük: reports from the 1995-1999 seasons. McDonald Institute for Archaeological Research and British Institute of Archaeology at Ankara. Cambridge, London, pp 137-202

Fairbairn A, Martinoli D, Buttler A, Hillman GC (2007) Wild plant seed storage at Neolithic Çatalhöyük East, Turkey. Veget Hist Archaeobot 16:467-479

Filipović D (2014) Early farming in Central Anatolia: an archaeobotanical study of crop husbandry, animal diet and land use at Neolithic Çatalhöyük. BAR International Series 2667. Archaeopress, Oxford

Filipović D, Bogaard A, Charles M, Fuller DQ (2014) Macro and micro botanical remains from the 2013 and 2014 seasons. In: Hodder I (ed) Çatalhöyük 2014 Archive Report. BIAA, Ankara and London, pp 118-130

Fuller DQ, Rowlands M (2011) Ingestion and food technologies: maintaining differences over the long-term in West, South and East Asia. In: Wilkinson TC, Sherratt S, Bennet J (eds) Interweaving worlds: systematic interactions in Eurasia, 7th to 1st millennia BC. Oxbow, Oxford, pp 37-60

Fuller DQ, Denham T, Arroyo-Kalin M, Lucas L, Stevens CJ, Quin L, Allaby RG, Purugganan MD (2014) Convergent evolution and parallelism in plant domestication revealed by an expanding archaeological record. PNAS 111:6,147-6,152

Goody J (1982) Cooking, cuisine and class: a study in comparative sociology. Cambridge University Press, Cambridge

Grimshaw RW (1971) The chemistry and physics of clays. Wiley, New York

Haaland R (2007) Porridge and pot, bread and oven: food ways and symbolism in Africa and the Near East from the Neolithic to the present. Camb Archaeol J 17:165-182

Hansson AM (2002) Pre- and protohistoric bread in Sweden: a definition and a review. In: Pain, fours et foyers des temps passés/ Bread, ovens and hearths of the past. Institut de Sociologie de l'Université de Bruxelles, Bruxelles, pp 183-190

Hansson AM, Isaksson S (1994) Analyses of charred organic remains. Laborativ Arkeologi 7:21-29

Hastorf C (1991) Gender, space and food in prehistory. In: Gero JM, Conkey MW (eds) Engendering archaeology: women and prehistory. Blackwell, London

Hastorf C (1998) The cultural life of early domestic plant use. Antiquity $72: 773-782$

Hastorf C (2005) Macrobotanical investigation: field methods and laboratory analysis procedures. In: Hodder I (ed) Inhabiting Çatalhöyük: reports from the 1995-1999 seasons. McDonald Institute for Archaeological Research and British Institute for Archaeology at Ankara, Cambridge and London, pp 129-137

Heiss AG (2010) Speisen, Holz und Räucherwerk. Die verkohlten Pflanzenreste aus dem jüngereisenzeitlichen Heiligtum von Ulten, St. Walburg, im Vergleich mit weiteren alpinen Brandopferplätzen. In: Steiner H (ed) Alpine Brandopferplätze. 
Archäologische und naturwissenschaftliche Untersuchungen/ Roghi votivi alpini. Editrice Temi, Trento, pp 787-813

Heiss AG (2012) Archäobotanische Analysen der Erdproben vom Brandopferplatz auf dem Ochsenberg. In: Schmid-Sikimic B, Pernet L, Wiemann P, Senn M (eds) Wartau - Ur- und frühgeschichtliche Siedlungen und Brandopferplatz im Alpenrheintal (Kanton St. Gallen, Schweiz), III. Eisenzeit. (UPA 217) Habelt, Bonn, pp 25-32

Heiss AG (2014) Ceremonial foodstuffs from prehistoric burntoffering places in the alpine region. In: Chevalier A, Marinova E, Peña-Chocarro L (eds) Plants and people: choices and diversity through time. Oxbow, Oxford, pp 343-353

Heiss AG, Pouget N, Wiethold J, Delor-Ahu A, Le Goff I (2015) Tissue-based analysis of a charred flat bread (galette) from a Roman cemetery at Saint-Memmie (Dep. Marne, ChampagneArdenne, north-eastern France). J Archaeol Sci 55:71-82

Hillman GC (1973) Agricultural resources and settlement in the Asvan region. Anatol Stud 23:217-224

Hillman GC (1981) Reconstructing crop husbandry practices from charred remains of crops. In: Mercer R (ed) Farming practice in British prehistory. Edinburgh University Press, Edinburgh, pp 123-162

Hillman GC (1984) Interpretation of archaeological plant remains: the application of ethnographic models from Turkey. In: Van Zeist W, Casparie WA (eds) Plants and ancient man. Balkema, Rotterdam, pp 1-41

Hodder I (2005) Socialization and feasting at Çatalhöyük: a response to Adams. Am Antiq 70:189-191

Hodder I (2006) The leopard's tale: revealing the mysteries of Çatal Höyük. Thames \& Hudson, London

Hodder I (2007) Çatalhöyük in the context of the Middle Eastern Neolithic. Ann Rev Anthropol 36:105-120

Hodder I (2011) Human-thing entanglement: towards an integrated archaeological perspective. J R Anthropol Inst 17:154-177

Hodder I (2012) Entangled: an archaeology of the relationships between humans and things. Wiley-Blackwell, London

Hodder I (2013) From diffusion to structural transformation: the changing roles of the Neolithic house in the Middle East, Turkey and Europe. In: Hofmann D, Smyth J (eds) Counterpoint: essays in archaeology and heritage studies. Archaeopress, Oxford, pp 349-362

Holden T (1990) Transverse cell patterns of wheat and rye bran and their variation over the surface of a single grain. Circaea 60:97-104

Jones G, Valamoti SM, Charles M (2000) Early crop diversity: a "new" glume wheat from northern Greece. Veget Hist Archaeobot 9:133-146

Jordan PD, Gibbs K, Hommel P, Silva F, Steele J (2016) Modelling the diffusion of pottery technologies across Afro-Eurasia: emerging insights and future research. Antiquity 90:590-603

Kohler-Schneider M (2001) Verkohlte Kultur- und Wildpflanzenreste aus Stillfried an der March als Spiegel spätbronzezeitlicher Landwirtschaft im Weinviertel, Niederösterreich. (Mitt Prähist Komm 37) Verlag der österreichischen Akademie der Wissenschaften, Wien

Kohler-Schneider M (2003) Contents of a storage pit from late Bronze Age Stillfried, Austria: another record of the "new" glume wheat. Veget Hist Archaeobot 12:105-111

Koon HEC, O'Connor TP, Collins MJ (2010) Sorting the butchered from the boiled. J Archaeol Sci 37:62-69

Kubiak-Martens L, Brinkkemper O, Oudemans TFM (2015) What's for dinner? Processed food in the coastal area of the northern Netherlands in the Late Neolithic. Veget Hist Archaeobot $24: 47-62$
Kuzmin YV (2013) Two trajectories in the neolithization of Eurasia: pottery versus agriculture (spatiotemporal patterns). Radicarbon 55:1,304-1,313

Lannoy S, Marinval P, Buleon A, Chiron H, Mejannelle P, Pin S, Rech J, Tchapla P (2002) Etude de "pains/galettes" archéologiques français. Civilisations 49:119-160

Last J, Ozdol S, Kapur E, Akca E, Serdem M, Kyzylarslanoglu A (2005) Pottery from the East Mound. In: Hodder I (ed) Changing materialities at Çatalhöyük: reports from the 1995-1999 seasons. McDonald Institute for Archaeological Research and British Institute for Archaeology at Ankara, Cambridge, pp 101-139

Lévi-Strauss C (1964) Mythologiques. Le cru et le cuit. Plon, Paris

Lévi-Strauss C (1988) The jealous potter. Chicago University Press, Chicago

Lyons DE, D'Andrea AC (2003) Griddle, ovens and agricultural origins: an ethnoarchaeological study of bread baking in highland Ethiopia. Am Anthropol 105:515-530

Maeda O, Lucas L, Silva F, Tanno K, Fuller DQ (2016) Narrowing the harvest: Increasing sickle investment and the rise of domesticated cereal agriculture in the Fertile Crescent. Quat Sci Rev 145:226-237

Mathew AJ, Woods AJ, Oliver C (1991) Spots before your eyes: new comparison charts for visual percentage estimation in archaeological materials. In: Middleton AP, Freestone IC (eds) Recent developments in ceramic petrology. (British Museum Occasional Paper 81). British Museum, London, pp 211-263

Moore AMT (1995) The inception of potting in Western Asia and its impact on economy and society. In: Hoopes JW (ed) The emergence of pottery. Technology and innovations in ancient societies. Smithsonian Press, Washington

Munro ND, Bar-Oz G (2005) Gazelle bone fat processing in the Levantine Epipalaeolithic. J Archaeol Sci 32:223-239

Oudemans TFM, Kubiak-Martens L (2013) Broad-spectrum cooking: botanical and chemical evidence in Late Neolithic Pottery. In: Kleijne JP, Brinkkemper O, Lauwerier RCGM, Smit BI, Theunissen EM (eds) A matter of life and death at Mienakker (the Netherlands): late Neolithic behavioural variability in a dynamic landscape. (Nederl Archeol Rapp 45) Rijksdienst voor het Cultureel Erfgoed, Amersfoort, pp 119-146

Pitter S, Yalman N, Evershed R (2013) Absorbed lipid residues in the Çatalhöyük pottery. In: Hodder I (ed) Substantive technologies at Çatalhöyük: reports from the 2000-2008 seasons. Cotsen Institute of Archaeology Press, Los Angeles, pp 193-201

Raemaekers DCM, Kubiak-Martens L, Oudemans TFM (2013) New food in old pots-charred organic residues in Early Neolithic ceramic vessels from Swifterbant, the Netherlands (43004000 cal BC). Arch Korr 43:315-334

Rice RW (1998) Porosity of ceramics. Marcel Dekker, New York

Rowlands M, Fuller DQ (2009) Moudre ou faire bouillir? Nourir les corps et les spirits dans les traditions culinaires et sacrificielles en Asie de l'Ouest, de l'Est et du Sud. Tech et Cult 52-53:120-147

Russell N, Martin L (2012) Cooking meat and bones at Neolithic Çatalhöyük, Turkey. In: Graff SR, Rodríguez-Alegría E (eds) The menial art of cooking: archaeological studies of cooking and food preparation. University Press of Colorado, Colorado, pp 87-93

Samuel D (1994) An archaeological study of baking and bread in New Kingdom Egypt. Doctoral Dissertation, University of Cambridge

Samuel D (1999) Bread making and social interactions at the Amarna Workmen's village, Egypt. World Archaeol 31:121-144

Samuel D (2000) A new look at old bread: ancient Egyptian baking. Archaeol Int 1999/2000:28-31

Sherratt A (1999) Diet and cuisine: farming and its transformations as reflected in pottery. Doc Praehist 29:61-72 
Speth JD (2012) Middle Palaeolithic subsistence in the Near East Before Farming 2012:1-45

Stahl AB (1989) Plant-food processing: implications for dietary quality. In: Harris D, Hillman GC (eds) Foraging and farming: the evolution of plant exploitation. Unwin Hyman, London, pp 171-197

Steensberg A (1990) Hard grains, irrigation, numerals and script in the rise of civilizations. Antiquity 64:968-969

Valamoti SM (2002) Food remains from Bronze Age-Archondiko and Mesimeriani Toumba in northern Greece? Veget Hist Archaeobot 11:17-22

Valamoti SM (2011) Ground cereal food preparations from Greece: the prehistory and modern survival of traditional Mediterranean 'fast food'. Archaeol Anthropol Sci 3:19-39

Valamoti SM, Samuel D, Bayram M, Marinova E (2008) Prehistoric cereal foods from Greece and Bulgaria: investigation of starch microstructure in experimental and archaeological charred remains. Veget Hist Archaeobot 17:265-276

Währen M (1989) Identifizierung von gesäuertem Brot in Knochenssasche-Kristallen einer urnenfelderzeitlichen Bestattung in Bellenberg (Ldkr. Neu-Ulm). (Kataloge der prähistorischen Staatssammlung München 23) Laßleben, Kallmünz

Währen M (2002) Pain, Pâtisserie et religion en Europe Pré- et Protohistorique. Origines et attestations cultuelles du pain. Civilisations 49:2-18

Wandsnider L (1997) The roasted and the boiled: food composition and heat treatment with special emphasis on pit-hearth cooking. J Anthropol Archaeol 16:1-48

Washburn EW (1921) Porosity. 1. Purpose of investigation. 2. Porosity and the mechanism of absorption. J Am Ceram Soc 4:916-922
Winton AL, Winton KB (1932) The structure and composition of foods. Wiley, New York

Wollstonecroft M (2007) Post-harvest intensification in Late Pleistocene Southwest Asia: plant food processing as a critical variable in Epipalaeolithic subsistence and subsistence change. Doctoral Dissertation, University College London

Wollstonecroft M, Ellis PR, Hillman GC, Fuller DQ (2008) Advances in plant food processing in the Near Eastern Epipalaeolithic and implications for improved edibility and nutrient bioaccessibility: an experimental assessment of Bolboschoenus maritimus (L.) Palla (sea club-rush). Veget Hist Archaeobot 17:19-27

Wollstonecroft M, Hroudová Z, Hillman GC, Fuller DQ (2011) Bolboschoenus glaucus (Lam.) S.G. Smith, a new species in the flora of the ancient Near East. Veget Hist Archaeobot 20:459-470

Wright K (1994) Ground-stone tools and hunter-gatherer subsistence in Southwest Asia: implications for the transition to farming. Am Antiq 59:238-263

Wright K (2000) The social origins of cooking and dining in early villages of Western Asia. Proc Prehist Soc 66:86-121

Wright K (2014) Domestication and inequality? Households, corporate groups and food processing tools at Neolithic Çatalhöyük. J Anthropol Archaeol 33:1-33

Yakar J (2000) Ethnoarchaeology of Anatolia. Rural socio-economyy in the Bronze and Iron Ages. Emery and Claire Yass Publications in Archaeology, Tel Aviv

Yalman N, Ozbudak DT, Gultekin H (2013) The Neolithic pottery of Çatalhöyük: recent studies. In: Hodder I (ed) Substantive technologies at Çatalhöyük: reports from the 2000-2008 seasons. Cotsen Institute of Archaeology Press, Los Angeles, pp 147-183 